\title{
"Even if it is Just a Little Help \\ for the Victims from the Distant Belgium": \\ Japanese Nationals in Belgium and the 3/11 Triple Disaster
}

\author{
Andreas Niehaus and Tine Walravens
}

\section{Introduction}

Anthropologists have argued that disasters "mobilize forces of cultural change" and that the potential fields of studies vary because disasters affect every aspect of human life, be it social, economic, environmental, political or even biological (Hoffman et al. 2002: 3-22). The theoretical approaches on disaster, however, take as their subject of study members of societies and cultures who were directly struck by disaster and limit their research spatially to the inflicted areas. Nevertheless, members of a given diaspora will also be deeply affected by catastrophe in their homeland. Rogers Brubaker (2005: 12) remarks that "as a category of practice, 'diaspora' is used to make claims, to articulate projects, to formulate expectations, to mobilize energies, to appeal to loyalties". It is, we will argue, in times of crisis and trauma that these practices construct, increase and intensify an awareness of community and evoke certain reactions generated by emotions, feelings and affects. When Japan was struck by the 3/11 Triple Disaster in 2011, Japanese nationals living in Belgium took a diasporic stance and immediately showed their commitment and loyalty by organizing charity events and moral support activities. ${ }^{1}$ Edith Turner (2012: 76) coined the term "communitas of

1 Figures obtained from the Japanese Embassy in Brussels show that all the overseas establishments of Japan (meaning, for example, all embassies and consulates, JETRO offices abroad) received J¥ 8.9 billion ( $=€ 88.5$ million) as of February 2012. The total amount which the Belgian Red Cross transferred to its Japanese counterparts is $€ 1,061,129$ or J¥ $116,563,464$ of which $€ 666,129$ was from the Flemish Red Cross and $€ 395$,00o from the Croix-Rouge de Belgique, Communauté francophone. Of that total amount, $€ 22$,000 came from gifts received by the Japanese Embassy in Belgium and $€ 315$,000 from gifts received by the BJA, the Belgium-Japan Association and Chamber of Commerce. These figures do not include donations and money from support actions organized by the Belgian community in Japan, nor donations transferred directly to the Japanese Red Cross or other organizations in Japan. Moreover, it seemed impossible to analyse what percentage of this money that has been donated by Belgians, Japanese individuals or companies in Belgium. See also Interview 1, May 22, 2012. 
disaster" in order to describe the feeling of togetherness that will result from a shared experience of a trauma. The parameter "shared experience", however, can be applied to different groups, creating different communitas as well as degrees of "sharedness" and separation. With regard to the Tōhoku Triple Disaster, "shared experience" firstly refers to the direct victims in Tōhoku and secondly to their families not living in the affected areas. ${ }^{2}$ However, "shared experience" can also refer to the idea of the Japanese nation, in contrast to other nations that were spared from the catastrophe. A further level of sharedness existed between the Japanese nationals living abroad at the time of the disaster and the Japanese nationals living in the home country. Although the group of Japanese living abroad long term or permanently still are and still feel Japanese, they will often be considered not Japanese "enough" by the Japanese living in Japan and by that denied "ownership" of the catastrophe. The disaster that struck Northern Japan thus creates a complex field where questions of identity, identification and belonging are tested and negotiated.

The disaster created diasporic communities that gave gifts with the purpose of supporting the homeland both materially and morally. Niko Besnier, referring to Joel Robbins, argues that these gifts also strengthen allegiance to the homeland: "intrinsic to giving and accepting is the mutual recognition of the other party, and thus the basis of self-conscious selfhood, which places the gift right at the center of a moral order. Remittances, then, bind the participants in a common moral order of mutual recognition. And so do that particular kind of remittances, gifts provided to help relief efforts in the wake of disaster" (Besnier 2009: 71-80). By linking remittances with the "crisis of return", we could argue that gift-giving will serve to show the solidarity of an individual as well as a group with the homeland, thus strengthening the feeling of belonging on both sides and securing a smooth return to the homeland for the short-term expatriates. In this context, we should also mention that donating and showing support manifested as a practice of communality; thus, it also created a sense of belonging (or exclusion) within the group of Japanese nationals living in Belgium.

2 The different levels of shared experience also applies to direct victims of Tōhoku because some will have lost family members or friends, while others will "only" have lost their property or material possessions. 
Based on fifteen in-depth interviews with Japanese nationals living in Belgium conducted between March and December 2012, ${ }^{3}$ this article will analyze how far their response as a social practice differed in relation to their residential status and to what extent they negotiated questions of identity, communality and group consciousness by engaging in support projects. Diasporic communities can generally be divided into short-term and long-term residents. For this study, we chose Brussels (the capital of Belgium) and Ghent (in the Flemish region) because the Japanese diasporic population in the former is characterized by a large number of short-term rotating individuals with a low degree of integration, while the Japanese nationals living in the latter are mainly permanent residents that are generally well integrated into the host community. In Ghent, we interviewed one short-term and five long-term Japanese residents. In Brussels, we conducted a total of nine interviews, seven of which were with Japanese short-term residents in Brussels. Additionally, we also interviewed a Japanese official at the Embassy of Japan and a Belgian representative of the Belgium Japan Association (BJA) Chamber of Commerce. We based our main approach on the assumption that diasporic communities are indeed characterized by practice. However, before focusing on how practice (re)created community following the triple disaster, it is necessary to map the ethnoscape of Japanese nationals in Belgium, based on the available official statistical data as well as the community's infrastructure.

\section{Mapping the Ethnoscape of Japanese Nationals in Belgium}

The Kingdom of Belgium, with a population of 9,832,010 (in 2011), is divided into three parts. The division is based on language, which, amongst other issues, fuels political and social conflict. Belgium has three official languages: Dutch, French and German. The Dutch speaking community is situated in the economically strong northern region of Flanders and the French speaking population in the Southern region of Wallonia. A minority of German-speaking Belgians lives

3 The interviews focused on questions concerning personal life, daily habits, interpersonal relations and network dynamics, organization of and participation in charity events, impact of the disaster on identity and feelings of belonging, media coverage. 
in the Eastern part of Wallonia. According to the most recent statistical data provided by the EUROSTAT population census, a total of 4,458 Japanese nationals were living in Belgium on January 1, 2011, of which 2,020 were male and 2,438 female. ${ }^{4}$

The majority of Japanese nationals who come to Belgium do so for remunerative reasons or family reunification with a Japanese national and will only stay short-term. ${ }^{5}$ However, Belgium also has a registered group of 901 long-term residents with Japanese nationality. ${ }^{6}$ Over the last three years, the number of Japanese nationals living in Belgium decreased due to the growing economic crisis facing Japan, which meant that companies reduced their overseas staff members, closed overseas offices or decided not to open new offices. The data received from the statistics show the Japanese expatriates in Belgium as comparable with other communities in Europe, for example, in Germany and the Netherlands. On the one hand, there are rotating, short-term residents of Japanese, primarily male, employees and their families working for transnational companies or for governmental institutions and whose residence is concentrated in urban centers such as Düsseldorf and Amsterdam. On the other hand, we find a primarily female group of long-term residents married to Belgians. ${ }^{7}$ Although its members

4 According to ADSEI (2012), there was a total population of 4,458 Japanese in 2011. As of January 1, 2010, a total of 4,543 Japanese were registered in Belgium. For 2010, see also ADSE (2011).

5 The first permits issued for family reasons and remunerative reasons are interrelated; from a total of 512 first permits for family reasons, 373 were issued on the basis of "person joining a non-EU citizen". In these cases, Japanese employees are joined by spouses, partners and children. However, it is interesting to note that the number of first permits for persons joining an EU-citizen more than doubled between 2010 (58) and 2011 (139), whereas the persons joining non-EU citizens decreased in absolute numbers from 412 in 2010. See Eurostat; Centrum voor gelijkheid van kansen en voor racismebestrijding (2011). First permits issued for remunerative activities accounted for 334 permits in 2011, with the majority issued for a period less than a year (303). Only 62 permits were issued for educational purposes, of which 58 were for studies, and 54 received a permit for less than a year Eurostat (2012). The number of Japanese students coming to Belgium dropped from 91 in 2008 to 58 in 2011.

6 In 2011, a total 901 Japanese citizens were registered as long-term residents in Belgium of which 72.6 percent (655) were female; (Eurostat).

7 When gender is taken into consideration, it shows that the first permit visa for remunerative activities in 2011 were mainly issued to male Japanese, accounting for 89.4 percent (262), with only 31 permits issued to female Japanese. As can be expected, the ratio is reversed in the case of first permits for family reasons (Eurostat). See also Centrum voor gelijkheid van kansen en voor racismebestrijding (2012). 
are primarily middle-class and residing in Belgium due to corporate rotation, the transient community in Belgium is quite diverse and will, as became evident from the interviews, generate formal and informal, mobile subgroups, based on occupation (company), place of residence, age of the children, gender or leisure interests. ${ }^{8}$

The highest concentration of Japanese citizens $(2,987$ in 2011) can be found in the county of Brussels. ${ }^{9}$ As Brussels is the capital of Belgium, home to the NATO headquarter and primary seat of the EU, it attracts a great number of Japanese companies and lobby organizations. ${ }^{10}$ It also houses Japanese governmental and semi-governmental organizations, including the Japanese Embassy to the Kingdom of Belgium, The Mission of Japan to the EU, EU-Japan Centre for Industrial Cooperation, Japan External Trade Organization Office (JETRO) and the Belgium-Japan Association and Chamber of Commerce (BJA, founded in 1991). Brussels houses a large international corporate and political expatriate community, whose members are well paid. They live in the more exclusive parts of the city and their social contacts often stay within the limits of this international expatriate community. Also, the Japanese living in Brussels as rotating, short-term residents are not well integrated into the host city but constitute a parallel society. However, the Japanese residents receive little to no attention from the host country. It seems that there is no direct need for the Japanese to integrate into Brussels' society. ${ }^{11}$ Brussels is actually situated in the Flemish part of the country but is mainly French speaking. Within the circles of the international corporate and diplomat community of Brussels, English and French

8 This pattern can also be observed in other European cities with a high concentration of Japanese, rotating short-term residents. See White (2003) and Befu (2001).

9 Reflecting the economical significance of the counties, 1,230 Japanese citizens live in Flanders (excluding Brussels) and 240 in Wallonia. See ADSEI (2011). The concentration of 3129 (2010) Japanese citizens living in Brussels makes the economic disparity even more significant when we take into consideration that 551 Japanese nationals are living in the province of Flemish-Brabant, which surrounds Brussels, and in the neighboring province of Walloon Brabant (91), which results in a percentage of 81.4 percent Japanese nationals living in the close vicinity of the capital.

${ }^{10}$ According to the Belgium-Japan Association, Chamber of Commerce (2011: editorial), there are about 220 Japanese companies registered in Belgium. Of these companies, 60 percent are situated in the county of Brussels; Interview 9, June 4, 2012.

${ }^{11}$ This has also been argued by Christian Tagsold (2011: 160). 
are the languages most commonly spoken, whereas Dutch plays no significant role. Accordingly, there is no practical reason for short-term Japanese residents to learn Dutch. ${ }^{12}$

It is generally agreed upon that short-term residents tend to reside in close proximity to each other, thus creating a sense of home in the host country. This is also true for the Japanese in the county of Brussels, where the majority of Japanese nationals in Belgium reside. When taking a look at the statistical data available concerning the Japanese population in Brussels, we see that in 2011 a total of 2,987 Japanese nationals were living in this county. Among those living in the county of Brussels, 1,991 Japanese residents are concentrated in only three municipalities from a total of nineteen municipalities in the county; these three municipalities are St. Lambrechts Woluwe, St. Pieters Woluwe and Oudergem (ADSEI 2011). If these data are cross-referenced with the prices of the real estate market in Brussels, we see that St. Lambrechts Woluwe and St. Pieters Woluwe have the highest rent for apartments in Brussels and that prices in Oudergem are also generally above average. Members of short-term rotating diasporas are aware of the fact that they will only stay temporarily in the host country and are thus less inclined to socialize with members of the host country or to adapt their life style. As Katarzyna Cwiertka argues concerning short-term employees in the Netherlands:

The "employees" follow the logistic decisions of their employers with little influence on their destinations. This, along with the temporary character of their residence, is the most important factor responsible for the formation of suspicious feelings towards foreign culture and a tendency to recreate a Japanese lifestyle outside Japan in order to leave their identity as untouched as possible. (Cwiertka 2002: 148)

However, Merry White also convincingly linked the creation and maintenance of a "Japanese" environment to the question of return, ascertaining that a Japanese life-style will make the re-entry into the Japanese culture easier: "Re-entry raises

${ }^{12}$ However, even within the circles of highly integrated, long-term Japanese residents living in the Flemish province, English is generally the lingua franca because the partners often do not speak Japanese; Interview 12, December 10, 2012. 
questions of identity that can be silenced only by strict conformity and virtual denial of the foreign experience." (White 1992: 106) ${ }^{13}$

Japanese short-term residents therefore create a sort of cultural island, an "ecology" that mimics the homeland, where members of the community can live a life according to their standards, needs and interests. ${ }^{14}$ Furthermore, the hierarchical group structures and social activities of the homeland are transferred and practiced in Belgium. The infrastructure in Brussels, mainly maintained by long-term Japanese residents, includes Japanese supermarkets, Japanese restaurants, Japanese recreational clubs, a Buddhist temple, a bulletin (Petits Pois, Jap. Puchi-Powa) and the Nihonjinkai (Association of the Japanese), a purely Japanese organization that promotes exchange between Belgium and Japan and supports the Japanese School of Brussels (JSB), which it founded in $1973 .{ }^{15}$ This private Japanese school provides an education that conforms to the Japanese educational system on weekdays and includes Japanese language education on Saturday morning (hosh $\bar{u} k \bar{o}){ }^{16}$ We see that mostly children from the short-term community attend the Japanese curriculum on weekdays, while Japanese staying permanently tend to enroll their children in the Belgian educational system and additionally send them to the Japanese school on Saturday mornings if they live in Brussels or the vicinity.

Because Japanese long-term residents in Brussels are often involved in providing logistic support and knowledge to short-term residents or work for Japanese companies, there is interaction between the two groups on the professional

\footnotetext{
${ }^{13}$ Interviewed short-term resident from Brussels commented on the decreasing numbers of applications from Japanese teachers wanting to go abroad. The interviewee gave the following reasons: low income, missing the development in Japan, and easier life in Japan; Interview 15, October 24, 2012.

${ }^{14}$ The term "ecology" here refers to an infrastructure providing stability, providing a "home abroad", a parallel society, a foreign community that produced its own environmental bubble (Tagsold 2011: 147).

${ }^{15}$ The bulletin, or information sheet (jōhō-shi), Petits Pois was first issued in 1992 by Japanese housewives and since 1993 has been registered as an association without lucrative purpose. Today, it is published at the beginning of every month (with the exception of August), eleven times per year and has a circulation of 2,000. Furthermore, fundraising and support events are advertised through this bulletin.

${ }^{16}$ The school has about 350 primary and junior high students (Japanese School of Brussels).
} 
level. However, the social worlds and private networks of both groups remain separated, as one interviewed short-term male resident in Brussels also stated. ${ }^{17}$

Belgium is a rather small country, approximately $30,500 \mathrm{~km}^{2}$; however the Japanese nationals living outside the direct vicinity of Brussels, such as the Japanese in Ghent, have hardly any contact with the Japanese nationals living in Brussels, Japanese organizations or even cultural activities that can be found in the capital. This is also true for the Japanese living in the city of Ghent. Ghent has a population of approximately 250,000; the city is situated in the Flemish region about 50 kilometers northwest of Brussels. The number of Japanese nationals registered in Ghent on December 31, 2011 was 62 (Gent City 2012: 66). Against the general overall trend seen in Belgium, the number of Japanese residing in Ghent is actually increasing. The Japanese expatriates in Ghent are dominated by female Japanese who are married to Belgian nationals. Most of those women are working outside of the household, in contrast to the professional housewife of the short-term Japanese community. Through their partners as well as their work environment, they are generally well integrated into the Flemish community, although the interviews suggest that social contacts are mainly with other Japanese or expatriates from other nations. Ghent also lacks the infrastructure for maintaining a Japanese lifestyle, including supermarkets to obtain ingredients for Japanese meals. There are a number of Japanese restaurants located in Ghent, but they depend on non-Japanese customers and are owned by non-Japanese who cash in on the recent sushi hype.

The children of the Japanese long-term residents living in Ghent are enrolled in the Belgian school system and on Saturdays additionally attend the Japanese school in Lille or, to a lesser degree, the Japanese school of/in Brussels. The choice for Lille, which is located just across the border to France, is firstly economically motivated, because the fees there are considerably lower. A second factor in Lille's popularity that was put forward by one of the interviewees is the "Japaneseness" of the school in Brussels:

Their [school in Lille] target is primarily half-blood children. But, that is my opinion, the quality of education in Brussels is also very good, but they try to

${ }^{17}$ Interview 15, October 24, 2012. 
do everything as it is done in Japan. The school in Lille is more for children that have another language [than Japanese] as mother tongue. ${ }^{18}$

Whereas the short-term residents choose an education based on the Japanese system in order to make the reintegration of their children into the Japanese school system easier, "doing it the Japanese way" is considered to be a disadvantage for the children of long-term residents because they are used to the Belgian system and will not need to adapt to the Japanese school system in the future.

In summary, we have observed that there are differences between short-term and long-term Japanese residents living in Belgium that range from life style, housing, schooling of children to social life and integration into the host country. In the following chapters, we will show that the aforementioned differences are parameters that have an influence on creating communality, belonging and identity through the practice of supporting the homeland.

\section{Supporting Home: Practicing Diaspora in Brussels and Ghent}

\subsection{Institutionalized Support: Japanese Short-Term Residents in Brussels}

Examining the fundraising events and support activities from the rotating shortterm community in Brussels, we see that the short-term residents have a low level of participation in the events organized outside the community and in the organization of support actions. If there were actions organized by the short-term community, they were aimed at and directed towards the community: Japanese supporting Japanese.

Institutions such as the embassy of Japan and the Nihonjinkai, an association for and by Japanese living in Belgium, did not organize any support actions. This tendency could be explained by the fact that the Nihonjinkai considers itself as receiving partner. ${ }^{19}$ The same is true for the embassy - it did not contact Japanese citizens actively and none of the respondents from the interviews had contacted it. A representative in Brussels explained that the embassy's limited role towards charity actions is due to the Japanese legal framework. ${ }^{20}$ Constrained by

\footnotetext{
${ }^{18}$ Interview 12, December 10, 2012.

${ }^{19}$ Interview 9, June 4, 2012.

${ }^{20}$ Interview 1, May 22, 2012.
} 
this framework, the embassy can neither take up a responsible role nor organize charity events by themselves; they are limited to supporting fundraising activities indirectly, for example through patronage. As such, the embassy was a patron of six support events. The embassy acted as an intermediary for the donations and tried to assist by disseminating information on several levels, such as the website and during cultural activities. The embassy also functioned as the official representative of the government and seemed to concentrate on restoring people's trust in the government and economy, thus limiting the economic damage. At an event attended by more than 800 invited guests and held in the Hilton Hotel in Brussels one year after the Triple Disaster, Ambassador Yokota Jun, speaking on behalf of the Nihonjinkai and the Ambassador of Japan to the European Union, Shiojiri Kojiro, openly addressed politicians and policy makers, asking them to lift the import restrictions and to support the Japanese economy. ${ }^{21}$ The event also included a minute of silence and promotional wine tasting. Also, JETRO focused worldwide on building up foreign investors' trust in the Japanese economy in general and in the stricken areas by organizing conferences and briefings for companies and business organizations. JETRO Brussels, for example, jointly with the Mission of Japan to the European Union, held a briefing for European companies and business organizations to explain countermeasures taken in response to the Great East Japan Earthquake (The Mission of Japan to the European Union 2011).

The business community in Brussels also engaged in activities, for example, the "HOPE" project of the Japanese car manufacturers in Belgium (Isuzu, Mazda, Nissan, Subaru, Suzuki and Toyota), through which these companies transferred $€ 20$ per car sold between March 11 and April 15, 2011 to the Japanese Red Cross

\footnotetext{
${ }^{21}$ Ambassador Yokota Jun also expressed his regret about EU import restrictions on Japanese products during a memorial service at the Japanese Garden in the city of Hasselt on November 3, 2012, which was attended by about one hundred Japanese and Belgians. As part of the ceremony, Yokota Jun together with the president of the Belgium-Japan Association planted a cherry tree; a plaque donated by the Belgium-Japan Association was placed. The event was framed by the female Japanese choir of Brussels and a group playing Japanese drums. The photograph that was placed above the Internet article in the Belgian newspaper De Morgen actually showed Asian faces with white face masks and candles. The photograph was not of the ceremony in Hasselt but of a "memorial demonstration" in Brussels mainly attended by anti-nuclear energy supporters.
} 
Society. A key organization in Belgian and Japanese business and cultural relations is certainly the Belgium-Japan Association, Chamber of Commerce (BJA). The BJA, with a primarily corporate-oriented membership, supported activities (e. g. charity concert by Seikyo Kim, May 13, 2011) and published a call for donations as early as March 14, 2011 (Belgium-Japan Association: 2011: 2). By March 30, thus within a mere fifteen days of the earthquake, they collected $€ 263,138$; this sum was then transferred to the Red Cross (Belgium-Japan Association: 1 ).

These events and briefings displayed a "male" official face, which stands in contrast to the "female" face of grassroots-level activities organized for the longterm Japanese network in Ghent (see below), where one long-term female resident remarked: "Japanese men organizing Zero."22 In the case of the short-term resident community in Brussels, it was not individuals which functioned as hubs, it was the organizations and companies. Japanese organizations and companies located in Brussels engaged in calls for financial support, donated money, and logistically supported or participated in events, but generally did not organize events by themselves. When events were organized, they stayed within the community in terms of both population and place. The Japanese School of Brussels can serve as an example; the school was contacted to participate in and promote different activities. ${ }^{23}$ The Japanese School of Brussels then decided to engage primarily in events that were somehow connected to children and education, for example with the European School of Brussels and Dyslexia International. They forwarded messages of support from different international schools in Brussels to Japan. The school itself organized a "writing characters of support" event and collected money as well, but these activities stayed within the boundaries of the school. ${ }^{24}$ One of the main charity events organized in Brussels was certainly the Japanese charity flea market on April 3, 2011 at the Notre Dame Church in Stockel, Sint-Pieters-Woluwe, a neighborhood with a high density of Japanese

\footnotetext{
${ }^{22}$ Interview 11, November 7, 2012.

${ }^{23}$ However, requests to use the school grounds for fundraising activities were denied.

${ }^{24}$ Interview 14, October 24, 2012. Interview 15, October 24, 2012. The money collected by the Japanese school was partially donated to a primary school in Miyagi through contacts of the former school director.
} 
expatriates. The initiative of the flea market came from a female Japanese longterm resident in Brussels, who had also experienced the Great Hanshin Earthquake in $1995 .{ }^{25}$ The flea market was officially coordinated on a volunteer basis by Misc Netto, a website organized by Japanese female volunteers living in Brussels, and the web company Beru tsū. Both support the Japanese short-term community in Belgium by organizing "sayonara sales" or by providing useful information on life and living in Belgium. ${ }^{26}$ Beru tsū (2011a), with 35,000 visitors per month on their website, is also well connected with social media and hosts a staff blog for members, distributes a "mail magazine" and created a webpage devoted to the triple disaster. The service offered by these websites is crucial for the Japanese expatriate community in Belgium, and the organizers were able to activate a broad network which attracted, according to the organizers, more than 3,000 participants and resulted in $€ 25,614$ from sales as well as donations. The funds were transferred to the embassy, which then donated the money to the Japanese Red Cross. The organizers also reached out to the Japanese School in Brussels, ${ }^{27}$ and information about the fundraising events was spread through the short-term community's information bulletin (minikomi) Petits-Pois (Puchi Powa). Thus, the organizers could rely on a well-established institutionalized and structural network. The volunteering participants were generally short-term Japanese residents in Brussels. The flea market also included a Japanese café, chocolate and cake shop, a shiatsu and origami workshop, Japanese drums demonstration and a concert by Japanese musicians, thus creating a "Japanese" atmosphere. Taking into account the special situation of Brussels, flyers were printed in four languages (Japanese, French, Dutch and English) and distributed mainly in the Japanese community as well as in cultural and corporate circles with a strong connection to Japan. The Japanese flyer, in contrast to the French, Dutch and English versions, explicitly made clear that the goods sold were donated following a call for donations and that all participants in the event, including the staff members of the organizing companies, were volunteers and that accordingly 100

${ }^{25}$ Interview 15, October 24, 2012.

${ }^{26}$ The company name Beru tsū can be translated as "Belgium Connoisseur". "Beru" can also mean "bells", which are represented in the logo.

${ }^{27}$ Interview 15, October 24, 2012. 
percent of the earned and donated money would go to the victims. Reading the Japanese language website of Beru tsū, it becomes clear that the charity bazaar is seen as an activity of a group of Japanese nationals that came together because they shared the same experience and wanted to do more than "just" individually donate money: "Even if it is just a little help for the victims from the distant Belgium." (Beru tsū 2011b) The impression of a "Japanese-helping-Japanese" event is also supported by the "Thank You Letter" (Orei to hōkoku) placed on the website (Beru Tsū 2011a).

The Triple Disaster - especially the nuclear catastrophe - resulted in largescale protests and an increasingly political civil society in Japan. The diasporic community in Brussels, however, limited itself to support activities, without participating in or organizing social and political protests. Several characteristics of the diasporic community contributed to the lack of politicization. The protest in Japan following the Fukushima catastrophe was carried out and sustained by students and furitā (freelance or unemployed people) up to the age of 30 and the age group above $50 .{ }^{28}$ The majority of the short-term Japanese nationals in Brussels, however, are career oriented and between 30 and 50 years old. This group in Brussels is also well integrated into a social network based on corporate affiliations (Nihonjinkai) with close ties to governmental institutions. Finally, the need to reintegrate after their return also meant that members of the community in Brussels did not take an openly critical position concerning the political establishment. ${ }^{29}$ Age structure, employment situation, social as well as corporate bonds that discourage political activities, and the need to reintegrate can explain the lack of political protest in Brussels.

\subsection{Activating Networks: Japanese Long-Term Female Residents in Ghent}

When focusing on the long-term residents in the city of Ghent, we discovered that the four interviewees do not consider themselves as part of a general Japanese diaspora. They belong to different informal "Japanese" sub-groups, formed

\footnotetext{
${ }^{28}$ For the protests in Japan following the nuclear catastrophe, see Gengenbach and Trunk (2012).

${ }^{29}$ One interviewed short-term resident from Brussels commented on the decreasing application of Japanese teachers wanting to go abroad by giving the following reasons: low income, missing the development in Japan and easier life in Japan; Interview 15, October 24, 2012.
} 
by the parameters of children (age and school), work place and social activities. These sub-groups form loose networks that are held together by the identity marker "homeland" and through events such as a New Year's dinner once a year, occasional "ladies nights", and activities with children.

All long-term interviewees in Ghent participated in several fundraising and support activities, usually events organized by Japanese friends or acquaintances. The members of the overlapping networks informed other members to spread the information on fundraising activities to such an extent that one interviewee from Ghent remarked: "It was impossible to go to all support events. There were just too many." ${ }^{30}$ The activities organized were directed towards an "outside", non-Japanese audience - mainly Belgians who are in one way or another connected to Japan economically or culturally - for example, students of Japanese studies, martial arts clubs, people who went to a Japanese concert or movie. The activities of these groups show a high degree of cultural knowledge of the host country because they are using events and networks in daily Belgian social life. The support and fundraising events organized by the permanent Japanese citizens were not initiated by a given and well-defined group but by individuals functioning as hubs. These Japanese individuals used their contacts to activate and rely on informal networks that are not limited to Japanese nationals.

The support events as reaction to the shared experience of shock, on the one hand, strengthened the networking system of the Japanese citizens and brought the participants closer together (although just for a short period of time); on the other hand, pre-existing trenches were reaffirmed: "The support activities did not really change the community of Japanese in Ghent, but people who did not want to do anything gave a weird feeling and the friendship has cooled down. We didn't want to press. We are disappointed." ${ }^{31}$

In the following section, we will exemplify these findings by focusing on the activities and support events initiated by two female permanent residents in Ghent. The flea market sales action at the church of St. Jacob in Ghent is a traditional, semi-professional flea market with regular stands and is held every

\footnotetext{
${ }^{30}$ Interview 11, November 7, 2012.

${ }^{31}$ Interview 12, December 10, 2012.
} 
week from Friday to Sunday; it is an excellent example of how the support actions of the permanent community were embedded into Belgian community life. A long-term, single, Japanese businesswoman in Ghent organized the charity sales action at this flea market, which was supported by other long-term female residents and their Belgian husbands. Selling at long-established, local markets requires a permit, which cannot be obtained easily. In the case of the support action, however, the organizer was able to use the reserved space of a friend and just needed a permit for this particular event. The products sold were donated by friends and acquaintances, contacted via e-mail, telephone, Twitter and Facebook, and included typical products that could be expected to be on sale at flea markets as well as products of Japanese origin. It was clearly marked that the products were sold for charity reasons and a charity box with a short explanatory text in Dutch and a hinomaru (flag of Japan) was placed on the sales stand as well. Because the regulations prohibit placing charity boxes on sales stands, a special permit was also obtained from the city hall. Using a traditional Belgian flea market for a support action requires cultural, structural and administrative understanding as well as an engagement with the city and its people. This kind of specific cultural knowledge, which also shows a certain degree of embeddedness into the host community and its social network, cannot be obtained by shortterm residents. When arguing from the point of network analysis, we can state that the organizers were able to find a common code of cultural communication, a code that could be understood by the members of the home community. ${ }^{32}$ The flea market itself was "broadcast" live on a video on the Ricobel blog, which is linked to the company of the organizer and meant for Japanese with an interest in Belgian culture.

Concerning the flea market in Ghent, the way the money was donated also shows a high degree of social network within the host community. Most charity actions donated the money directly to the Red Cross in Japan or Belgium. In the case of the flea market sale in Ghent, the organizers bought toys and sweets for children and sent these to the city of Kanazawa, from where they were finally forwarded to the areas hit by the triple disaster. Choosing Kanazawa seems odd

${ }^{32}$ For network analysis, see especially Blumer (1992). 
at first because Kanazawa is about 420 kilometers away from Fukushima prefecture. However, the organizer was aware of the fact that Ghent and Kanazawa are sister cities, and through personal contacts in Ghent's city hall, she was able to use her social network for this action. In this sense, the action also strengthened the Ghent-Kanazawa connection. Besides speaking of a communality of practice, it is also important to mention the communication of practice, for example, the dissemination and publication of support activities, fundraising and donations. The gift-giving was also mentioned in two newspaper articles in the Hokkoku Shimbun, a regional tabloid from Kanazawa. In the article, the toys and sweets received were clearly marked as gifts from an individual Japanese female living in Ghent, Belgium. The two headlines read: "From Belgium to the children of the stricken area. Mrs. Ō from Ghent entrusts the city with toys and sweets" and the second header refers to the gifts as "Belgian toys to the stricken areas. Mrs. Ō from Ghent City. Entrusting sister city Kanazawa." The latter article also shows two photos of the gifts being placed on a conference table and arranged by a Caucasian woman (in one photo also watched by a Japanese woman) who, although not identified in the article, is the Belgian Coordinator of International Affairs at Kanazawa City Hall.

Support activities obviously have the intrinsic meaning of offering material and moral relief to the disaster-stricken regions. However, the activities also serve the secondary purpose of creating communality and belonging; therefore, it is crucial to communicate the realized activities and the gift-giving of those "inside" the community to those on the "outside".

An excellent example for the importance of communication is the production of three videos by the above-mentioned businesswoman with messages of support and sympathy for the victims in Japan.Thus, support activities were not limited to providing financial and material support; they also extended to activities such as offering messages of solidarity that were meant to give moral support. These messages were considered to be equally important as financial or material support, which Ruth Martin also shows in her analysis of support activities in London for the triple disaster. The people who appeared in the two videos, "A support message from Belgium (1)/ (2) Be strong, Japan! (Berugī kara 


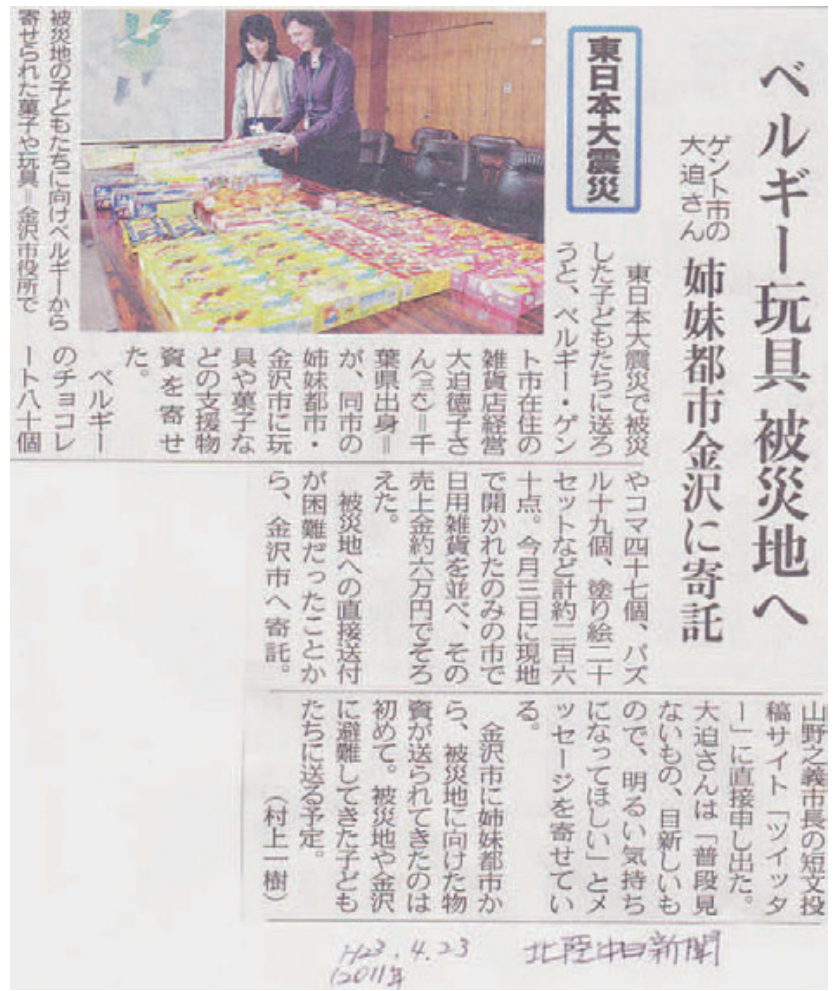

ōen messēji [1]/ [2] Ganbare Nippon!)", were Ghent citizens, one city official, local traders or teachers, and students from Ghent University, all somehow connected to Japan or to the Japanese living in Ghent or visiting the city. Among them was the chocolatier on the Korenlei (a famous tourist spot), who counts many Japanese tourists among his clientele. The Let's Speak Japanese Club (Nihongo hanasō kai) from Antwerp also added a message of encouragement. The third video was a personal message from the mayor of Ghent, Daniel Termont. The oral English and Japanese messages were subtitled in Japanese and placed on YouTube as well as on the aforementioned Ricobel blog. The comments posted on both sites as well as numerous letters sent to Ghent University show that Japanese in the homeland indeed seemed to notice and appreciate the messages sent. Japanese 
national TV station NHK also chose certain scenes for a sequel of support messages from all over the world that was shown regularly in commercial breaks the months following the triple disaster.

The videos of support were born from the personal experience of shock, which resulted in the urge to support the Japanese in the stricken areas. ${ }^{33}$ However, the videos can also be linked to the corporate world because the Ricobel blog, where the videos were posted, is run by the Ricobel company, which is also mentioned at the end of the video messages.

In the second example, another individual female employee in Ghent utilized the work environment for organizing support activities. She functioned as hub in at least two fundraising events. Inspired by the example of a Japanese colleague's sister who folded and sold tsuru (origami cranes) in Japan, she and the colleague participated in the Orizuru_PrayforJapan support activity and folded origami cranes together with volunteering colleagues. On the Orizuru_PrayforJapan website (2011), the company receives special thanks from the organizers. The organizers visited other offices in their building and sold the cranes for the victims of the disaster for the price of $€ 1$. This activity was extended to the private context by organizing tsuru activities at the schools of the interviewees' children and also at the judo club of one of the children. The paper crane is a basic origami figure that can easily be folded and is thus very well suited for a group activity involving children. In one case, after obtaining permission from the school director, the two Japanese women - dressed in kimonos - visited all classes in this school over a period of two days and folded cranes together with the attending school children. The children then went home to sell the cranes to their parents, friends and neighbors. In a second activity, the annual Japanese film festival Japan Square, of which one interviewee is board member, served as platform for a tsuru sale action. ${ }^{34}$ In both cases the organizers donated the money to the Red Cross Flanders and also received permission to use the Red Cross logo (Orizuru_PrayForJapan 2011; Shinema tudei 2011).

\footnotetext{
${ }^{33}$ Interview 11, November 7, 2012.

${ }^{34}$ Interview 12, December 10, 2012. Interview 13, December 10 2012. On March 11, 2012 the film festival also showed the film A Sketch of Mujo, a documentary on the Tōhoku disaster.
} 
In contrast to the above-mentioned flea market activity, the tsuru activity was based on and made use of stereotypical and easily recognizable elements of Japanese culture for their fundraising activity, thereby making the activity readily identifiable as an activity related to Japan. ${ }^{35}$ The crane is a bird of cultural significance in Japan, expressing hope, long life, recovery from illness and injury, peace, and now increasingly stands for solidarity. Through the tragic story of the Hiroshima atom bomb victim Sasaki Sadako, the crane is well known also in Belgium as a symbol of nuclear disarmament. The link with the nuclear catastrophe of Fukushima made the crane a symbol that could also be interpreted as protest against nuclear energy. The Japanese embassy also received a number of origami cranes (single or in a string of 1000 senbazuru), which were displayed in a special exhibition at the Cultural and Information Centre of the embassy as token of gratitude following the triple disaster. ${ }^{36}$

\section{Practicing Communality}

The support activities by Japanese nationals living in Belgium - long-term or short-term - were marked by the commitment to their home country. When Japanese artists organised exhibitions, classical concerts and other charity events under the name "ACT FOR JAPAN", they stated that the group's purpose is to provide relief to the "homeland":

We are trying to unite our efforts and act to support our home country. From Belgium, where we are blessed with a rich cultural environment and opportunity to share our art, we pray for Japan's rebirth and declare the message that no matter how hard it may be, Japan will rise up and shine again, just like the sun always rises in the morning. In this time of darkness, Japan needs your

${ }^{35}$ This activity was referred to as "Japan Square-Tsuru Ladies" in the Trade Flows \& Cultural News, the official magazine of the Belgium-Japan Association, Chamber of Commerce, and has a circulation of 2,500 print copies.

${ }^{36}$ Also other Japanese and Belgians who organized fundraising events and moral support activities also used the crane as trademark that could easily be recognized, for example, The Dinner of the Rising Sun in the Palace of the Colonies (Tervuren, Brussels) on May 26, 2011. For the price of $€ 200$, which was donated to the Red Cross, guests were served a four-course dinner by Japanese and Belgian top chefs. The event was organized by a non-profit organization, whose representative is the sushi-chef of the Antwerp-based restaurant Ko'uzi, Kawada Junko, a long-term resident. The names of the chefs as well as the names of their restaurants were mentioned on the advertisement. 
support. Until the day we overcome the difficulties and smile again, we will join our hands and act for Japan. (Act for Japan 2011) ) $^{37}$

Long-term residents often tend to display a romantic, idealized, as well as stereotypical view of their home country, which becomes - borrowing a term Marilyn Ivy (1995) used - a kind of "internal exotic". For Singapore, Eyal Ben-Ari (2003: 128) states: "the Japanese expatriates discover their 'Japanese-ness". The websites and flyers of support events display elements of a stereotypical and romantic (or even better, nostalgic) construction of Japan and Japaneseness. This practice of preserving and even exhibiting a distinctive identity vis-à-vis the host society can be linked to one of the core elements of a diaspora, which according to Brubaker is "boundary-maintenance" (Brubaker 2005). The triple disaster consequently increased a sense of being Japanese and the awareness of Japanese cultural identity, as one short-term resident from Brussels remarked:

We became aware again about the bad and good sides of being Japanese. There are good things like immediate organization of reconstruction, but the chaos also let the dark sides of the people come to light, for example, profiting from the confusion, taking away or stealing things from others, not taking into consideration the situation at hand. We are used to thinking that these things do not exist in our society, but they do. The will to survive, to protect oneself, and to rescue was overwhelming. I think that the Japanese as a nation did not take enough responsibility for what has happened. ${ }^{38}$

The way the community tried to recover and reconstruct resulted in a feeling of togetherness and also in a promise to the future, based on the construction of ties between people.

Even before [the triple disaster] I had met these people [who were organizing the flea market], but I also met other Japanese people through them, and by organizing this flea market together, it felt as though the power of solidarity (danketsuryoku ga umareta) as Japanese emerged. ${ }^{39}$

\footnotetext{
${ }^{37}$ The website also displays a message to the victims of the triple disaster in the Töhoku region. It is striking that the term furusato is used when referring to Japan: "What had happened in our home(land)." The term "furusato", which Christine Yano (2002: 17) refers to as "the focal point of nostalgia and memory" refers, on the one hand, to one's (rural) place of birth and to the "idea of originary, emotive space and homeland", on the other hand (Robertson 1991: 5, 14).

${ }^{38}$ Interview 8, May 24, 2014.

${ }^{39}$ This quote was made by a short-term resident in Brussels and is taken from an online questionnaire conducted by BA and MA students at Ghent University in 2011.
} 
This quote is especially striking because the phrase danketsuryoku ga umareta, which is translated here with the "power of solidarity emerged", can also mean the "ability to join activities emerged". This, first of all, refers to something that was felt to be absent thus far, namely a feeling of solidarity as a Japanese, a feeling that Japan lacked a civil society, ${ }^{40}$ or as one interviewee put it: "Before I used to think that Japanese are egoistic, but this is changing now. They now know that we have to help each other. [...] They are more concerned. Their heart's eye has opened." ${ }^{41}$

Yet, where in Japan the term kizuna (binding) was used to describe the feeling of standing together after the catastrophe, none of the participants used this word in describing the feeling of solidarity. Even more, the above quote suggests a complex field of inclusion and exclusion because the speaker creates an emotional distance with the Japanese back "home" by using the grammatical markers of "I", "we" and "they".

\section{Conclusion}

We have argued that a group creates or re-confirms itself (from within) through practice. Despite the differences between both long-term and short-term diasporic communities, the triple disaster and its aftermath served as a catalyst for increased communication on a personal level within the community. As such, the (closed) community of short-term Japanese nationals strengthened and reinforced their ties within the Japanese community, while the permanent Japanese nationals in Belgium strengthened their contacts with other Japanese, and also reached out to Belgian nationals for participation in charity events. However, the strengthening of togetherness was - because the practice of support

\footnotetext{
${ }^{40}$ For the definition of the term "civil society" in Japan, see especially Ducke (2007). In Japan, the redefinition of the cultural and social system and the rediscovery of the civil society is coined in the term kizuna (bonds; connection), which was chosen to be the word of the year in 2011. For the controversial discussion of the term kizuna in Japan, see Tagsold (2012). Already in December 2011, a new political party named New Kizuna (Shintō Kizuna) was founded; it exploited the term kizuna for political ends. The party dissolved before the general election in December 2012. The main political aims were economic oriented and were directed against the proposal to raise the consumption tax as well as against the Trans-Pacific Partnership Agreement. See Kizuna Party.

${ }^{41}$ Interview 3, June 8, 2012.
} 
was limited in time - only a temporary manifestation, following the first months after the triple disaster. The support events also served as a means to further define network boundaries because not all Japanese nationals were equally willing to participate in volunteer activities. The organization of support actions thus strengthened already-existing divisions and provided an acceptable reason for further alienation. Support activities not only strengthened the awareness of "Japaneseness" and of being Japanese, but also added - at least temporarily - the notion of a "civil society" as a new element of Japaneseness: the ability to stand together and support each other in times of catastrophe not only individually or locally but also nationally. In Japan, this feeling of solidarity also meant a politicization of civil society, whereas the support activities of the diasporic community in Belgium, in essence, remained apolitical and supportive of the existing political system.

\section{Literature}

ACT FOR JAPAN. 2011. http://www.actforjapan.be/"'page_id=20. (accessed January 15, 2013)

ADSEI - Algemene Directie Statistiek en Economische Informatie. 2010. Bevolking per nationaliteit, geslacht, leeftijdsgroepen op 1/1/2010. http://statbel.fgov.be/nl/mod ules/publications/statistiques/bevolking/population_natio_sexe_groupe_classe_d_ges_au_1er_janvier_ 2010.jsp. (accessed 13 January, 2013)

ADSEI - Algemene Directie Statistiek en Economische Informatie. 2011. ht tp://statbel.fgov.be/nl/modules/publications/statistiques/bevolking/downloads/bevolking_per_nationali teit_per_gemeente_01-01-2011.jsp. (accessed January 13, 2013)

Belgium-Japan Association, Chamber of Commerce. 2011. Trade Flows \& Cultural News. 92.

Befu, Harumi, “The Global Context of Japan Outside Japan.” In: Befu, Harumi; GuichardAnguis, Sylvie (eds.): Globalizing Japan. London, New York: Routledge: pp. 3-22.

Ben-Ari, Eyal. 2003. "The Japanese in Singapore: The Dynamics of an Expatriate Community." In: Goodman, Roger; Peach, Ceri; Takenaka, Ayumi; White, Paul (eds.): Global Japan: The Experience of Japan's New Immigrant and Overseas Communities. London, New York: Routledge, pp. 116-130.

BERU Tsū. 2011a. Tōhoku Kantō daishinsai ni tsuite. http://www.bel2.jp/home/earthquake.html. (accessed January 15, 2013)

BERU TSŪ. 2011b. Tōhoku chihō taiheiyō oki jishin chariti bazā. http://www.bel2.jp/PNG/hom e/bazaar/bazaar\%20flyer\%20JP.pdf. (accessed January 15, 2013) 
Besnier, Niko; Robbins, Joel. 2009. "Equality, Inequality, and Exchange." In: Journal of the Finnish Anthropological Society 34 (4): pp. 71-80.

Blumer, Herbert. 1992. "Der methodologische Standort des symbolischen Interaktionismus.” In: Burkart, Roland; Hömberg, Walter (eds.): Kommunikationstheorien: Ein Textbuch zur Einführung. Wien: Wilhelm Braumüller, pp. 23-39.

Brubaker, Rogers. 2005. “The 'Diaspora' Diaspora." Ethnic and Racial Studies 28 (1): $1-19$.

Centrum Voor GeLIJKHEID VAN KANSEN EN VOOR RACISMEBESTRIJDING. 2011. Jaarverslag Migratie 2010. Brussels.

CENTRUM VOOR GELIJKHEID VAN KANSEN EN VOOR RACISMEBESTRIJDING. 2012. Jaarverslag Migratie 2011. Brussels.

CwiErtka Katarzyna. 2002. "Eating the Homeland: Japanese Expatriates in the Netherlands." In: Cwiertka, Katarzyna; Walraven, Boudewijn (eds.): Asian Food. The Global and the Local. London, New York: Routledge, pp. 133-152.

Ducke, Isa. 2007. Civil Society and the Internet in Japan. London, New York: Routledge.

EUROSTAT. 2012. http://epp.eurostat.ec.europa.eu/portal/page/portal/population/data/database. (accessed January 13, 2013)

Gengenbach Katrin; Trunk, Maria. 2012. "Vor und nach $>$ Fukushima<: Dynamiken sozialer Protestbewegungen in Japan seit der Jahrtausendwende." In: Chiavacci, David; Wieczorek, Iris (eds.): Japan: Politik, Wirtschaft und Gesellschaft. Berlin: VSJF, pp. 261-282.

Gent City. 2012. Demografische gegevens 2011. https://stad.gent/sites/default/files/page/docume nts/demo2011.pdf. (accessed January 15, 2013)

GlebE, Günther. 2003. "Segregation and the Ethnoscape: The Japanese Business Community in Düsseldorf." In Global Japan: The Experience of Japan's New Immigrant and Overseas Communities Goodmann, Roger; Peach, Ceri; Takenaka, Ayumi; White, Paul (eds.) London, New York: Routledge, pp. 98-115.

Hoffmann, Susanna M.; Oliver-Smith, Anthony. 2002. "Why Anthropologists Should Study Disaster." In: Hoffman, Susanna M.; Oliver-Smith, Anthony (eds.): Catastrophe \& Culture. The Anthropology of Disaster. Santa Fe: School of American Research Press, pp. 3-22.

Ivy, Marilyn. 1995. Discourses of the Vanishing: Modernity Phantasm Japan. Chicago, London: U of Chicago P.

JAPANESE SCHOOL OF BRUSSELS. /www.japanese-school-brussels.be/JSBHPenglish3.pdf. (accessed January 13, 2013)

KIZUnA PARTY. http://www.kizuna-party.jp/. (accessed January 15, 2013)

MiscNetTo. http://www.misc-net.com/. (accessed January 15, 2013) 
OrIZURU PrayForJaPAN. 2011. http://orizuruprayforjapan.blogspot.be/. (accessed January 15, 2013)

Petits-Pois. http://www.petits-pois.be/. (accessed January 15, 2013)

RoBertson, Jennifer. 1991. Native and Newcomer: Making and Remaking a Japanese City. Berkeley: U of California P.

Shinema tUdeI. 2011. Berugī de "shinboru" "yattaman" nado wadaisaku o shūchū jōei no nihon eigasai kaisai". http://www.cinematoday.jp/page/N0031568. (accessed January 15, 2013)

TAGsold, Christian. 2011. "Establishing the Ideal Foreigner: Representations of the Japanese Community in Düsseldorf Germany." In: Encounters 3 (1): 143-168.

TAGsold, Christian. 2012. "Das Schriftzeichen des Jahres 2011 als Antwort auf das gefühlte Auseinanderbrechen der Gesellschaft.” In: Chiavacci, David; Wieczorek, Iris (eds.): Japan: Politik, Wirtschaft und Gesellschaft. Berlin: VSJF, pp. 309-328.

The Mission of Japan to the European Union. 2011. Countermeasures for the Great East Japan Earthquake: Briefing for European Companies and Business Organisations. http://www.eu.emb-japan.go.jp/Countermeasures $\% 20$ for $\% 20$ the $\% 20$ Great $\% 20$ East $\% 20$ Japan $\% 20$ Ear thquake.html. (accessed January 15, 2013)

Turner, Edith. 2012. Communitas: The Anthropology of Collective Joy. New York: Palgrave Macmillan.

White, Merry E. 1992. The Japanese Overseas: Can They Go Home Again? Princeton, NJ: Princeton UP.

White, Paul. 2003. “The Japanese in London. From Transience to Settlement.” In: Roger Goodman; Ceri Peach; Ayumi Takenaka; Paul White (eds.): Global Japan: The Experience of Japan's New Immigrant and Overseas Communities. London, New York: Routledge: pp. 79-97.

Yano, Christine R. 2002. Tears of Longing. Nostalgia and the Nation in Japanese Popular Songs. Cambridge, London: Harvard UP, 2002). 